\title{
INVESTIGATING ENGLISH LECTURERS' STRATEGIES OF COMMITTING ONLINE WRITTEN CORRECTIVE FEEDBACK DURING COVID-19 PANDEMIC
}

\author{
${ }^{1,2}$ Ahmad Hanan, ${ }^{1}$ Edi Firman, ${ }^{1}$ Terasne \\ ${ }^{1}$ English Lecturer, FBMB, Universitas Pendidikan Mandalika, Indonesia \\ ${ }^{2}$ Co. Author Email: ahmadhanan@undikma.ac.id
}

\begin{tabular}{|c|c|}
\hline Article Info & Abstract \\
\hline $\begin{array}{l}\text { Article History } \\
\text { Received: November } 2021 \\
\text { Revised: December } 2021 \\
\text { Published: January } 2022\end{array}$ & $\begin{array}{l}\text { Written corrective feedback is essential in the teaching of writing skills to help } \\
\text { prospective teacher enhance their writing performance. Lecturers try to apply } \\
\text { strategies in committing written corrective feedback in fully online learning. In } \\
\text { addition, written corrective feedback can improve learners' metalinguistics, }\end{array}$ \\
\hline $\begin{array}{l}\text { Keywords } \\
\text { Lecturers' Strategies; } \\
\text { Online Learning; } \\
\text { Written Corrective } \\
\text { Feedback; }\end{array}$ & $\begin{array}{l}\text { metacognition, teachers-learners interaction, and peer connection. Consequently, } \\
\text { the present study will be aimed at investigating English lecturers' common } \\
\text { practices and strategies in committing online written corrective feedback during } \\
\text { Covid-19 pandemic at higher education. This study is classified as a qualitative } \\
\text { study which is a descriptive qualitative study. It is chosen because the data of this } \\
\text { study relates to opinions or attitudes in the form of lecturers' strategies in the } \\
\text { teaching of writing skills and online corrective feedback. The data are elaborated } \\
\text { in the form of words, phrases, sentences, and paragraphs. To attain the data, } \\
\text { researchers use interview technique. There are five English lecturers involved in } \\
\text { the current study. The data are analyzed by using qualitative processes which are } \\
\text { data condensation, data display, and conclusion drawing or verification. The } \\
\text { novelty of this study lies on written feedback, written corrective feedback, and } \\
\text { online written corrective feedback. Due to Covid-19 pandemic, the teaching- } \\
\text { learning process is done in fully online learning. }\end{array}$ \\
\hline
\end{tabular}

How to cite: Hanan, A., Firman, E., \& Terasne. (2022). Investigating English Lecturers' Strategies of Committing Online Written Corrective Feedback during Covid-19 Pandemic, JOLLT Journal of Languages and Language Teaching, 10(1), pp.46-55. DOI: https://doi.org/10.33394/jollt.v\%vi\%i.4471

\section{INTRODUCTION}

Written corrective feedback has attracted attention of researchers who have concerns of second language (L2) writing, L2 acquisition, and foreign language (FL) writing (Bitchener \& Storch, 2016; Papi et al., 2020). Many researchers emphasize their focuses on the effect of corrective feedback, but little bit on prospective teachers' strategies to minimize their errors and lecturers' strategies to help practice teachers improve their writing performance (Sheen, 2010; Lee, 2019). Historically, written corrective feedback is carried out in relation to writing errors, linguistic accuracy, and metalinguistic features in general (organization and content of a written text).

Writing instruction that incorporates written corrective feedback is considered a learning technique to attract prospective teachers' attention to linguistic forms in their writing texts and also to enhance their linguistic acquisition (Benson \& DeKeyser, 2019; Sippel, 2019). Because of this, lecturers should respond all written errors made by their prospective teachers so that prospective teachers are helped to improve their written accuracy (Sato \& Loewen, 2018). Lecturers provide their prospective teachers with comments of contents, organization, and other essential issues in their writing products. In considering the importance of giving written corrective feedback, researchers investigate English lecturers' strategies of committing online written corrective feedback in the current study during Covid19 pandemic at higher education. 
With the web-based technology and mobile learning development, the internet and mobile application are widely employed in written corrective feedback (Goa, Moses, \& Adelina, 2016; Dewit, Siraj, \& Alias, 2014; Du, 2013). Some internet social media platforms are utilized for online written corrective feedback (Zhu, 2013; Gao, Samuel, \& Asmawi, 2016). In the online learning, lecturers do not carry out no nonverbal activities of prospective teachers learning or cognitive engagement. For lecturers to know that a prospective teacher is present, the prospective teachers have to engage with the course content in a manner that indicates visible traces in the online classroom.

During Covid-19 pandemic, lecturers provide prospective teachers with online written corrective feedback in the teaching of writing skills in Indonesia higher education institutions, including the study program of English language education at Mandalika University of Education, West Nusa Tenggara. Most lecturers around the world carry out their teaching and learning in fully online learning (Ranalli, 2019; Ma, 2019). In giving online written corrective feedback, lecturers employ various strategies because they believe that elaborative feedback has benefits and potential to improve prospective teachers learning, foster engagement, and increase learners' satisfaction (Espasa \& Meneses, 2010; Mandernach, 2018; Huun, 2018).

The online written corrective feedback strategies applied by lecturers should be useful to develop prospective teachers' writing performance. Gao and Ma (2019) depict that online written corrective feedback must be focused on prospective teachers' metalinguistic because they can be helped in developing new structures. It is in line with Shintani \& Ellis (2013) who argue that online corrective feedback using computer helps learners or prospective teachers to proceduralize their explicit knowledge of new structures. The efficacy of online written corrective feedback is conducted in two strategies which are direct and indirect written corrective feedback strategy (Gao \& Ma, 2019; Chukharev-hudilainen \& Saricaoglu, 2016). In the present study, researchers investigate English lecturers' strategies of committing online written corrective feedback for prospective teachers' writing tasks during Covid-19 pandemic at higher education institutions.

Written corrective feedback is different from oral corrective feedback. Written corrective feedback occurs after prospective teachers complete their writing, while oral corrective feedback commonly occurs shortly or immediately after prospective teachers commit an error (Jacob, Lachner, \& Scheiter, 2020; Lyster \& Saito, 2010). In other words, written corrective feedback allows lecturers to do this in online while prospective teachers are in the process of composing their sentences, paragraphs, or texts. Therefore, the current study is directed to investigate English lecturers' strategies of committing online written corrective feedback.

The strategies of providing online written corrective feedback are assumed to be able to improve lecturer-prospective teacher interaction and peer interaction. In online courses, prospective teachers are given writing tasks to practice writing and at the end, they generate a complete text. The novelty of this study lies on written feedback, written corrective feedback, and online written corrective feedback. Due to Covid-19 pandemic, the teaching-learning process is done in fully online learning. In doing so, English lecturers need strategies of conducting online written corrective feedback. The strategies employed by lecturers are able to not only enhance prospective teachers' cognitive comprehension of teaching materials, but it can provide a strategy or mechanism for encouraging motivation, interpersonal interaction, and engagement.

\section{Teaching Writing Skills in Higher Education}

In Indonesia, English is taught as compulsory subject from middle schools into higher education. In English language study program, writing is one of language skills should be acquired by English prospective teachers in higher education, Indonesia. It is considered as the most difficult language skill to be mastered (Haerazi, Utama, \& Hidayatullah, 2020; Yuan 
\& Stapleton, 2020). Most prospective teachers feel uneasy to write their ideas into a piece of papers, including academic writing or non-academic writing. Therefore, writing is taught consecutively from 1st semester to 4th semester (Haerazi et al., 2020). Writing learning activities are applied to help them to acquire the skills. Those include process-oriented learning activities and product-oriented learning activities.

\section{Online Learning during Covid-19 Pandemic}

During Covid-19 pandemic, English teaching-learning is carried out in online learning or fully online learning. The lecturers and prospective teachers interact with each other virtually and fully online activities. Fully online learning is able to encourage learners' active learning and integrative learning (Lomicka, 2020). It is also capable of enhancing learners' persistence, retention, and satisfaction (Lord \& Lomicka, 2014). Online learning leads lecturers to become a professional one who has incredible foresight (Paesani, 2020) and teaching experiences (Song, 2015; Borg, 2012).

\section{Written Corrective Feedback}

In English as a foreign language teaching and learning, lecturers address their attention to how prospective teachers are able to communicate orally and in written. In the written context, the potential language learning benefits is giving feedback (Ellis, 2010; Ebyary \& Windeat, 2010; Milla \& Mayo, 2013). Feedback in writing refers to correction on an error made by learners or prospective teachers. Lecturers applied different strategies to correct prospective teachers' errors. They might address the text' content in which lecturers give comments the way its ideas are organized and presented (Beuningan, 2010). Theoretically, written corrective feedback is different from oral corrective feedback (Lee, Mak, \& Burn, 2015).

\section{RESEARCH METHOD \\ Research Design}

The current study follows a qualitative work which is a descriptive qualitative study. This study aims to investigate the English lecturers' strategies of implementing online written corrective feedback in the teaching of writing skills during Covid-19 pandemic at higher education. It is chosen because the data of this study relates to opinions or attitudes in the form of lecturers' strategies in the teaching of writing skills and online corrective feedback. The research issues cover lecturers' common practice and lecturers' strategies in giving corrective feedback on prospective teachers' writing tasks or products through online activities during covid-19 pandemic. The data are elaborated in the form of words, phrases, sentences, and paragraphs (Cohen, Manion, \& Morrison, 2018). The main data of the current study comprise lecturers' common practices and strategies in committing online written corrective feedback.

\section{Research Object}

The research objects of this study are English lecturers who teach writing subject from Level 1 to Level 4 (academic writing). There are five English lecturers involved in the current study. This study will be conducted at English language education of the Faculty of Culture, Management, and Business at UNDIKMA. It is chosen because the institution accreditation is Level B which is accredited by National Board Accreditation of Higher Education (BAN-PT). In addition, English lecturers involved in this study are certified by Ministry of National Education and Culture. They have long experiences of writing teaching-learning.

\section{Instruments}

The present study will use an interview technique to attain the data, which is interview sheets. The interview is unstructured interview activities. It is generally emphasizing researchers to conduct long-term activities and allow respondents to express their own ways 
and pace (Miles Huberman, \& Saldana, 2016). The contents of interview session deal with lecturers' common practices in written corrective feedback and their strategies in conducting online written corrective feedback in the teaching of writing skills. The session of interview activities in this study resembles a conversation more than an interview and it is also controlled conversation in line with the interest of this study (Mile, Huberman, \& Saldana, 2018; Creswell \& Creswell, 2018). To administer optimum use of interview time, questions are provided more and less 10-15 interview items. The items of questions can be added and reduced. This depends on the respondent situation.

\section{Data Analysis}

The data of this study cover opinions and arguments collected using interview activities. The interview is done in line with researchers and lecturers' agreements as the object of this study. It is, of course, carried out at the end of semester. The data will be analyzed by using qualitative ways which are data condensation, data display, and conclusion drawing or verification (Miles, Huberman, \& Saldana, 2018). The data of this study will be lecturers' common practices in giving written corrective feedback and lecturers' strategies in conducting online written corrective feedback. In the step of data condensation, researchers select, abstract, and transform information given by lecturers in the form of sentences and paragraphs until the messages contain research points.

In data condensation session, the data are also coded and summarized in accordance with each information needed. Thus, researchers classify each information in the form of Table and Matrix. Afterwards, the data are organized and decided which information is taken to be explored and elaborated on the rows and columns. It is then called the phase of data display (Miles, Huberman, \& Saldana, 2018). In the phase of conclusion drawing or verification, researchers interpret and elaborate data founded in the form of conclusion sentences based on each research issue. The conclusion is then verified to strengthen whether the data are suitable or not with the research issues.

\section{RESEARCH FINDINGS AND DISCUSSION Research Findings}

This study investigates lecturers' strategies of committing online written corrective feedback in the teaching of writing skills during covid-19 pandemic. Based on the results of interview, lecturers provide their corrective feedback for students in various strategies. The strategies are applied to correct students' written texts. The strategies can be seen in Table 1 . The strategies are focused on two common types of feedback, direct feedback and indirect feedback. In the context of grammatical correction, the lecturers' feedback focused on errors in grammar (syntax and morphology), lexis (referring to word choices), and mechanics (relating to spelling and punctuation).

Table 1.

Lecturers' Strategies of Committing Written Corrective Feedback

\begin{tabular}{ll}
\hline Written Feedback Types & Lecturers' Strategies \\
\hline Direct Feedback & Reformulating students' texts: \\
& Rewriting students' texts but keeping the original meaning as much as \\
& possible \\
& Inserting the correct phrase and changing phrase order \\
& Repairing verb form and adjunction of sentences \\
\hline Indirect Feedback & Eeleting verbs of sentences \\
& Repetition (Recast/Videos) \\
& Metalinguistic clues \\
& Explicit correction \\
\hline
\end{tabular}


The analysis revealed that the online written corrective feedback appeared in several forms. From five writing lecturers involved in this study, all lecturers stated that the online corrective feedback was delivered in two types of feedback, directive feedback and indirective feedback. During interview session, three teachers were more outspoken and overtly involved in detailed discussion about written corrective feedback. Most teachers reported that in online learning during covid-19 pandemic they tended to provide their students with direct feedback. It was provided in the form of reformulating the student' text. Lecturers attended to grammatical and lexical errors in the students' text and with feedback on their writing immediately. The following excerpts reflect such writing feedback practices.

...when I provide correction on my students' text, I always focus on errors in grammar, word choices, spelling, and mechanics. Also, I give a correction to students' text with reformulating students' text. For instance, I give insertion of phrases, a change of phrase order, and verb correction. Although I correct the students' text, the original text of students is preserved from the original meaning...

During online learning, I used several correction techniques. For instance, recast technique is the most frequent type I provided for my students. I explained how to use English articles, sub-clauses in making compound sentences, and subject-agreement. In the recast technique, I also focused on metalinguistic information by providing them with some examples as the model text.

Most lecturers agreed with the efficacy of written corrective feedback in both online and offline learning in the teaching of writing courses. Lecturers reported that direct feedback was carried out in a range of formats such as crossing out unnecessary words, sentences, and morphemes. This strategy was shared by a member of the interviewees in this study.

The generated text of some students should be corrected directly. It was that I called direct feedback. The direct feedback was given when my students indicate errors and I provided with correct forms. The correct forms can be represented in a range of morphemes, words, sentences, and adding missing contents near to the incorrect sections. For outstanding students, this feedback was effective to help them produce a good writing text in one side. It will be insufficient correction for low level students on the other hand. Therefore, I sometime recast the corrective feedback online for those students.

Lecturers also reported that indirect feedback was effective to help students produce good writing texts. Three teachers to four teachers provided comments of indirect written corrective feedback. They define indirect written corrective feedback is the indication of an error without an explicit correction. Herein, students diagnose and correct any issues given by lecturers.

Unlike with direct feedback, I applied the indirect feedback in the form of underlining the error and using codes where the errors existing. Also, I elaborate implicitly the content of texts as to has cohesive devices, the idea related to the intention of personal view. This strategy can be positive impact when it is applied appropriately. In my class, this feedback was effective for graded students because it forced students to engage in guided learning and problem-solving.

Similarly, I also conduct indirect written feedback in my writing classes. In doing indirect written feedback, I felt that students are involved in developing their text autonomously. I just provide metalinguistic information related to the generated text. Students diagnosed and reformulate the text. The reformulation was focused on phrase order, verb form, content, organization, and ideas.

Indeed, the strategy of online written corrective feedback in the teaching writing classes has brough various impact for both lecturers and students. Members of the discussion (interviewees) believed that the direct and indirect written feedback become a common marking practices and strategies in higher education to help students generate good texts. 


\section{Discussion}

In response to the research questions of this study, the lecturers' strategies of committing online written corrective feedback are predominantly focused on two types of strategies, namely direct and indirective feedback. In terms of direct feedback, lecturers concerned students' text reformulation. The reformulation of students' texts was carried out by rewriting students' texts but keeping the original meaning. Lecturers provided some codes in which the errors existed. They often inserted the correct phrases and change the phrase order in students' text. In doing so, lecturers mostly give codes such as correction of verb form, a change of phrase order or insertion of the phrase, deletion of sentence verbs, and adjunction of the sequential sentences (second sentence to become first sentence). This strategy was effective for students to find the error grammar and word meanings although this feedback tended to provide students with enough time to read the reformulation. The current findings were different from what Storch and Wigglesworth (2010) found that the reformulation strategy was not extensive in the level of students' engagement. Because of this, students did not have good time to identify the nature of errors and try to supply the correct form. In online corrective feedback, it is not necessarily reflecting depth of students' cognitive processes (Mila \& Mayo, 2013; Tocalli-Beller \& Swain, 2005).

Compared to online written direct feedback, indirect feedback in this study showed that it can facilitate students more to have metalinguistic information effectively than directive feedback. Indirective feedback strategy relates to students' writing errors in retention (editing symbol strategy). Students have enough opportunity to understand and identify the errors (Storch \& Wigglesworth, 2010; Bitchner \& Storch, 2016). At the same time, students can utilize their grammar knowledge to understand what lecturers commented on their text. In this case, students were involved in extensive engagement. In doing so, lecturers provide online indirect feedback with using email and WhatsApp devices. It was focused on metalinguistic clues and explicit and implicit correction on students' texts. Most lecturers applied their feedback in providing metalinguistic information. According to them, metalinguistic clues enabled students to improve and develop their grammar knowledge so that they applied it to correct their texts in line with lecturers' comments and suggestions (Stefanou \& Revesz, 2015; Karim \& Nassaji, 2020).

Most of studies founding an impact on corrective feedback have focused on only limited a number of errors rather than a range of editing forms, whether it was conducted in Asynchronous and synchronous learning. In this study, most lecturers declared that comprehensive strategy (indirect feedback) has been assumed to become more effective than focused feedback strategy (indirect feedback) in relation to students' extensive engagement. The current findings were different from the previous studies founding direct feedback was effective than comprehensive one (e.g., Sheen, 2007; Bitchener \& Knoch, 2008; Ellis et al., 2008; Sheen et al., 2009; Nassaji, 2015). The reason was that the processing comprehension demanded students cognitively to understand first the metalinguistic information provided. Therefore, students need more instruction to interpret the error codes (Ferris, 2004; Amrhein \& Nassaji, 2010). The lecturers' feedback strategies are mostly directed to grammatical errors. Then, errors were oriented to treatable and untreatable errors.

Most English lecturers of writing classes in this study informed that treatable errors were assumed as more effective than untreatable one. Lecturers provided their students with codes relating to language forms such as verb tense, article usage, and subject-verb agreement. This helps students revise their texts easily. Compared to treatable errors, untreatable errors demanded students to think much more the language choice, collocation, unidiomatic sentence structure, missing and unnecessary words. Therefore, lecturers felt this strategy was less effective. These findings of the current study were supported by some previous studies mentioned in the literature review (Sheen et al., 2009; Ellis, 2010; Ebyary \& 
Windeat, 2010; Milla \& Mayo, 2013; Nassaji, 2015). They did correction feedback for students very often on students' texts. In doing so, lecturers provide implicit correction on students' texts by giving codes to revise and edit according to grammatical errors.

\section{CONCLUSION}

This study aims to investigate lecturers' strategies of committing online written corrective feedback in the teaching of writing skills during covid-19 pandemic. The lecturers' strategies of committing online written corrective feedback are predominantly focused on direct and indirective feedback. In terms of direct feedback, lecturers concerned students' text reformulation. The reformulation of students' texts was carried out by rewriting students' texts but keeping the original meaning. Lecturers provided some codes in which the errors existed. They often inserted the correct phrases and change the phrase order in students' text. Compared to online written direct feedback, indirect feedback in this study showed that it can facilitate students more to have metalinguistic information effectively than directive feedback. Indirective feedback strategy relates to students' writing errors in retention (editing symbol strategy).

Lecturers provide online indirect feedback with using email and WhatsApp devices. It was focused on metalinguistic clues and explicit and implicit correction on students' texts. Most lecturers applied their feedback in providing metalinguistic information. The reason was that the processing comprehension demanded students cognitively to understand first the metalinguistic information provided. Most English lecturers of writing classes in this study informed that treatable errors were assumed as more effective than untreatable one. Lecturers provided their students with codes relating to language forms such as verb tense, article usage, and subject-verb agreement. This helps students revise their texts easily. Compared to treatable errors, untreatable errors demanded students to think much more the language choice, collocation, unidiomatic sentence structure, missing and unnecessary words. Therefore, lecturers felt this strategy was less effective.

\section{ACKNOWLEDGEMENT}

Researchers would like to thank the LPPM UNDIKMA that funded this study. Also, researchers thank the Dean of FBMB that provides opportunity to carry out this study at the English Language Education Study Program.

\section{REFERENCES}

Amrhein, H.R., \& Nassaji, H. (2010). Written corrective feedback: what do students and teachers prefer and why? Canadian Journal of Applied Linguistics, 13, 95-127.

Benson, S., \& DeKeyser, R. (2019). Effects of written corrective feedback and language aptitude on verb tense accuracy. Language Teaching Research, 23(6), 702-726. https://doi.org/10.1177/1362168818770921

Beuningen, C. Van. (2010). Corrective Feedback in L2 Writing: Theoretical Perspectives, Empirical Insights, and Future Directions. International Journal of Language Studies, 10(0), 1-27. https://doi.org/https://doi.org/10.6018/ijes/2010/2/119171

Bitchener, J., \& Storch, N. (2016). Written corrective feedback for L2 development. Multilingual Matters.

Bitchener, J., \& Knoch, U. (2008). The value of written corrective feedback for migrant and inter- national students. Language Teaching Research Journal, 12, 409-431.

Borg, S. (2012). Current approaches to language teacher cognition research: A methodological analysis. In R. Barnard \& A. Burns (Eds.), Researching language 
teacher cognition and practice: International case studies (pp. 11-29). Bristol, England: Multilingual Matters.

Chukharev-hudilainen, E., \& Saricaoglu, A. (2016). Causal discourse analyzer: improving automated feedback on academic ESL writing. Computer Assisted Language Learning, 8221(February), 0-23. https://doi.org/10.1080/09588221.2014.991795

Cohen, L., Manion, L., \& Morrison, K. (2018). Research Methods in Education (8th Edition). New York: Routledge.

Creswell, J. W., \& Creswell, J. D. (2018). Research Design: Qualitative, Quantitative, and Mixed Methods Approaches (Fifth Edition). In Journal of Chemical Information and Modeling (Vol. 53, Issue 9). Los Angeles: Sage Publication. https://doi.org/https://lccn.loc.gov/2017044644

DeWitt, D., Siraj, S., \& Alias, N. (2014). Collaborative m-Learning: A module for learning secondary school science. Educational Technology \& Society, 17(1), 89-101

Dippold, D. (2009). Peer feedback through blogs: Student and teacher perceptions in an advanced German class. ReCALL, 21, 18-36.

Du, Q. J. (2013). On course design of business English teaching based on QQ platform. Overseas English, 7, 106-108.

Ebyary, K., \& Windeat, S. (2010). The Impact of Computer-Based Feedback on Students' Written Work. International Journal of Language Studies, 10(2), 121-142. https://doi.org/https://doi.org/10.6018/ijes/2010/2/119231

Ellis, R. (2010). Epilogue: A framework for investigating oral and written corrective feedback. Studies in Second Language Acquisition, 32(2), 335-349. https://doi.org/10.1017/S0272263109990544

Ellis, R., Sheen, Y., Murakami, M., \& Takashima, H. (2008). The effects of focused and unfocused written corrective feedback in an English as a foreign language context. System, 36, 353-371.

Ferris, D. (2004). The 'grammar correction' debate in L2 writing: Where are we, and where do we go from here? (and what do we do in the meantime ...?). Journal of Second Language Writing, 13, 49-62

Gao, X., Moses, M., \& Adelina, A. (2016). Online Features of Qzone Weblog for Critical Peer Feedback to Facilitate Business English Writing. Journal of Educational Technology Systems, 45(2), 285-301. https://doi.org/10.1177/0047239516659865

Gao, J., \& Ma, S. (2019). The effect of two forms of computer-automated metalinguistic corrective feedback. Language Learning and Technology, 23(2), 65-83. https://doi.org/https://doi.org/10125/44683

Ghosn-chelala, M., \& Al-chibani, W. (2018). Screencasting: Supportive Feedback for EFL Remedial Writing Students. International Journal of Information and Learning Technology. https://doi.org/10.1108/IJILT-08-2017-0075

Haerazi, H., Utama, I. M. P., \& Hidayatullah, H. (2020). Mobile Applications to Improve English Writing Skills Viewed from Critical Thinking Ability for Pre-Service Teachers. International Journal of Interactive Mobile Technologies (IJIM), 14(07), 58. https://doi.org/10.3991/ijim.v14i07.11900

Haerazi, H., Irawan, L. A., Suadiyatno, T., \& Hidayatullah, H. (2020). Triggering Preservice Teachers' Writing Skills through Genre-Based Instructional Model Viewed from Creativity. International Journal of Evaluation and Research in Education, 9(1), 234244. https://doi.org/10.11591/ijere.v9i1.203945 
Huun, K. (2018). Student Prsence and Faculty Availability in Fully Online Course: Is Alignment Requisite? Journal of Educators Online, 15(2). https://www.thejeo.com/archive/2018_15_2/huun_kummerow

Jacob, L., Lachner, A., \& Scheiter, K. (2020). Learning by explaining orally or in written form? Text complexity matters. Learning and Instruction, 68(October 2019), 101344. https://doi.org/10.1016/j.learninstruc.2020.101344

Karim, K., \& Nassaji, H. (2020). The revision and transfer effects of direct and indirect comprehensive corrective feedback on ESL students' writing. Language Teaching Research, 24(4), 519-539. https://doi.org/10.1177/1362168818802469

Lee, I. (2019). Teacher written corrective feedback: Less is more. Language Teaching, 52(4), 524-536. https://doi.org/10.1017/S0261444819000247

Lee, I., Mak, P., \& Burns, A. (2015). Bringing Innovation to Conventional Feedback Approaches in EFL Secondary Writing Classrooms. English Teaching: Practice \& Critique, 14(2), 140-163. https://doi.org/https://doi.org/10.1108/ETPC-02-2015-0004

Lomicka, L. (2020). Creating and sustaining virtual language communities. Foreign Language Annals, 53(2), 306-313. https://doi.org/10.1111/flan.12456

Lord, G., \& Lomicka, L. (2014). Twitter as a tool to promote community among language teachers. Journal of Technology and Teacher Education, 22(2), 187-212. Retrieved from https://www.learntechlib.org/primary/p/49768/

Lyster, R., \& Saito, K. (2010). Oral feedback in classroom SLA: A meta-analysis. In Studies in Second Language Acquisition (Vol. 32, Issue 2). Kean University. https://doi.org/10.1017/S0272263109990520

Ma, J. (2019). The effect of two forms of computer-automated metalinguistic corrective feedback. Language Learning and Technology, 23(2), 65-83. https://doi.org/https://doi.org/10125/44683

Mandernach, B. J. (2018). Strategies to Maximize the Impact of Feedback and Streamline Your Time. Journal of Educators Online, 15(3). Retrieve from https://www.thejeo.com/archive/archive/2018_153/mandernachpdf

Miles, M. B., Huberman, A. M., \& Saldana, J. (2016). Quantitative Data Analysis: A Methods Sourcebook (Third). Los Angeles: Sage Publication.

Milla, R., \& Mayo, M. P. G. (2013). Corrective feedback episodes in oral interaction: A comparison of a CLIL and an EFL classroom. International Journal of Language Studies, 14(1), 1-20. https://doi.org/https://doi.org/10.6018/ijes/14/1/151841

Nassaji, H. (2015). The interactional feedback dimension in instructed second language learning: Linking theory, research, and practice. London: Bloomsbury.

Paesani, K. (2020). Teacher Professional Development and Online Instruction: Cultivating Coherence and Sustainability. Foreign Language Annals, 53(2), 292-297. https://doi.org/10.1111/flan.12468

Papi, M., Bondarenko, A., Wawire, D., Jiang, C., \& Zhou, S. (2020). Feedback-seeking behaviour in second language writing: Motivational mechanisms. Reading and Writing, 33, page $485-$ 505. https://doi.org/10.1007/s11145-019-09971-6

Ranalli, J. (2019). The affordances of process-tracing technologies for supporting L2 writing instruction. Language Learning and Technology, 23(2), 1-11. https://doi.org/https://doi.org/10125/44678 
Sato, M., \& Loewen, S. (2018). Metacognitive Instruction Enhances the Effectiveness of Corrective Feedback: Variable Effects of Feedback Types and Linguistic Targets. Language Learning, 68(2), 507-545. https://doi.org/10.1111/lang.12283

Sheen, Y. (2010). Differential effects of oral and written corrective feedback in the ESL classroom. In Studies in Second Language Acquisition (Vol. 32, Issue 2). https://doi.org/10.1017/S0272263109990507

Sheen, Y. (2007). The effect of focused written corrective feedback and language aptitude on ESL learners' acquisition of articles. TESOL Quarterly, 41, 255-283.

Sheen, Y., Wright, D., \& Moldawa, A. (2009). Differential effects of focused and unfocused writ- ten correction on the accurate use of grammatical forms by adult ESL learners. System, 37, 556- 569.

Shintani, N. (2015). The effects of computer-mediated synchronous and asynchronous direct corrective feedback on writing: a case study. Computer Assisted Language Learning, February, 37-41. https://doi.org/10.1080/09588221.2014.993400

Shintani, N., \& Ellis, R. (2013). The comparative effect of direct written corrective feedback and metalinguistic explanation on learners' explicit and implicit knowledge of the English indefinite article. Journal of Second Language Writing, 22, 286-306. https://doi.org/10.1016/j.jslw.2013.03.011

Sippel, L. (2019). The impact of peer corrective feedback on vocabulary development. Foreign Language Annals, 52(3), 595-611. https://doi.org/10.1111/flan.12416

Song, S. Y. (2015). Teacher beliefs about language learning and teaching. In M. Bigelow \& J. Ennser-Kananen (Eds.), The Routledge handbook of educational linguistics (pp. 263275). New York, NY: Routledge.

Stefanou, C., \& Révész, A. (2015). Direct Written Corrective Feedback, Learner Differences, and the Acquisition of Second Language Article Use for Generic and Specific Plural Reference. Modern Language Journal, 99(2), 263-282. https://doi.org/10.1111/modl.12212

Storch, N. (2010). Critical Feedback on Written Corrective Feedback Research. International Journal of English Studies, 10(2), 29. https://doi.org/10.6018/ijes/2010/2/119181

Storch, N., \& Wigglesworth, G. (2010). Learners processing, uptake, and retention of corrective feedback on writing: Case studies. In Studies in Second Language Acquisition (Vol. 32, Issue 2). https://doi.org/10.1017/S0272263109990532

Strickland, B. M. (2019). Writing for the (virtual) other: Bakhtinian intertextuality within online L2 writing exchanges. Language Learning Journal, 47(1), 1-18. https://doi.org/10.1080/09571736.2016.1146915

Tocalli-Beller, A., \& Swain, M. (2005). Reformulation: The cognitive conflict and L2 learning it generates. International Journal of Applied Linguistics, 15, 5-28.

Xianwie, X., Samuel, S., \& Asmawi, A. (2016). A model of critical peer feedback to facilitate Business English Writing using Qzone weblogs among Chinese undergraduates. Malaysia Online Journal of Educational Technology, 4(4), 1-17. https://doi.org/https://doi.org/10.17220/mojet

Yuan, R., \& Stapleton, P. (2020). Student teachers' perceptions of critical thinking and its teaching. ELT Journal, 74(1), 40-48. https://doi.org/10.1093/elt/ccz044 